\title{
The Spending Responses to Adverse Health Shocks: Evidence from a Panel of Colombian Households
}

\author{
Darwin Cortés* $\quad$ Andrés Gallegos ${ }^{\dagger} \quad$ Jorge Pérez Pérez \\ This draft: January 15th, $2021 .^{\S}$
}

\begin{abstract}
We analyze the effect of adverse health shocks on households' different expenditure shares using a difference in differences approach. We find that households engage in substitution between health and food spending in response to the negative health shocks. We find substantial heterogeneity in this trade-off between current and future health mediated by access to social protection, job contract type, and location (urban-rural). Households from rural areas, with heads holding informal jobs, and without access to safety nets, are more vulnerable than others. We discuss several policy implications.
\end{abstract}

JEL Codes D12, I15, J46

*Universidad del Rosario and Alianza EFI. E-mail: darwin.cortes@urosario.edu.co.

$\dagger$ Universidad del Rosario. E-mail: german.gallegos@urosario.edu.co.

${ }^{\ddagger}$ Banco de México. E-mail: jorgepp@banxico.org.mx.

$\S$ We thank Julieth Pico, Diego Mayorga, Gabriel Suárez and Sergio Rivera for research assistance. We also thank Claudia Quintero and Nicolás Fuertes for assistance with the ELCA data. We thank Seema Jayachandran, Mrinal Mishra, Paul Rodríguez-Lesmes, Andrés Zambrano, and participants at the Economics of Informality Conference for comments and suggestions. The views and conclusions presented in this paper are exclusively the responsibility of the authors and do not necessarily reflect those of Banco de México. We acknowledge financial support from Fulbright - Colciencias and Colombia Científica - Alianza EFI \#60185 contract \# FP44842- 220-2018, funded by The World Bank through the Scientific Ecosystems, managed by the Colombian Ministry of Science, Technology and Innovation (MINCIENCIAS). 


\section{Introduction}

How do households react to negative shocks that may alter their income constraint? Consumer theory suggests that agents should adjust their expenditure on different goods according to their income elasticity when income changes. However, these spending adjustments may change because of other circumstances surrounding households, such as their degree of insurance and their sources of income. Understanding the origins of heterogeneity in these responses is vital for the design of social protection programs (Blundell et al., 2020).

In this paper, we study the spending response to adverse health shocks using household data from Colombia. We document substantial differences in the spending response to negative shocks between urban and rural households. We examine the mechanisms behind these heterogeneous responses focusing on the role of labor informality and insurance.

The Colombian setting is attractive for three reasons. First, Colombia is an increasingly urban developing country, where the urban share of the population has grown by $9 \%$ in the last three decades. This process of urbanization has led to a sizeable urban-rural divide in development indicators. In such a setting, the response to adverse health shocks may differ starkly across urban and rural areas. Second, Colombia has a high degree of labor informality. The percentage of informal workers, defined as those without access to employer-financed health insurance, was 56\% in January 2020. Informal workers have fewer alternatives to deal with adverse shocks because they have less access to insurance and more volatile income. Third, Colombian households often experience adverse health shocks. In our sample, $25 \%$ report experiencing adverse shocks in the previous ten years.

To examine the spending response to adverse health shocks, we use two panel-data waves on urban and rural households in Colombia from 2013 to 2016. We create a harmonized dataset of household spending in several item categories across the dataset's two waves. We model the demand on each item category as a function of prices, income, and demographics, following specifications from the demand system estimation literature (Deaton and Muellbauer, 1980; Pollak and Wales, 1981; Barnett and Serletis, 2008). We then compare households who experienced adverse health shocks to those who did not suffer them. We do this by allowing the demand functions to shift in response to shocks, and we estimate these shifts through a two-way fixed-effects analysis. Our approach follows that of Attanasio et al. (2011), who embed a difference- 
in-differences analysis in consumer theory-inspired Engel curves to assess the response of food spending to cash transfers. Our identification assumption is that in the absence of adverse health shocks, the shares of spending in each item category we consider would evolve in parallel across unaffected and affected households, conditional on household demographics and the occurrence of other shocks. The panel nature of the data allows us to control for time-invariant heterogeneity across households using fixed effects. The panel analysis contrasts with other studies that rely on repeated cross-section data or synthetic panel methods (Attanasio and Székely, 2004).

We find that health shocks induce large spending adjustments that vary between household types. Food and health spending react strongly to health shocks. Rural households increase their health spending share by around five percentage points (pp) and substitute away from food spending, reducing its budget share by about three pp. Urban households increase their health spending by about one pp and reduce their food spending share by $1.8 \mathrm{pp}$. These differences across rural and urban households do not arise from different baseline spending or different income responses to the adverse shocks.

Our estimates show a substantial role of insurance and formal employment as sources of the observed heterogeneity in responses. Among urban households, those where the household heads have formal jobs do not reduce their food spending in response to adverse health shocks. In contrast, urban households with informally-employed heads and rural households reduce their food spending by $4 \mathrm{pp}$. Households with access to formal safety nets such as a conditional cash transfer program, or informal safety nets such as risk-sharing with neighbors, do not substitute away from food spending to weather adverse health shocks.

Our work contributes to the literature on consumption responses to health and income shocks in developing countries. Many of these papers have focused on the Indonesian case. Gertler and Gruber (2002) show that households in Indonesia are unable to entirely smooth consumption against shocks arising from severe illness. Genoni (2012) shows that these illness-related shocks also reduce income in Indonesian households and that transfers act as a coping strategy. Sparrow et al. (2014) show that the negative response of income to shocks comes mostly from poor rural households, while other households can smooth spending. Our results for the Colombian case confirm that rural households cannot level off the shocks and highlight substitution away from food spending as a shock response.

On coping strategies, Gertler et al. (2009) show that access to finance may help 
households smooth consumption against these shocks. Wagstaff (2007) shows that families with more inactive working-age members may adjust to the shock by sending these members to the labor force. In their case, rural households are more insured because they usually have more idle able members. We also find that larger households can smooth their spending when they are affected by a health shock. Access to formal and informal insurance also allows these households to maintain their levels of food spending.

Our paper also contributes to the literature on expenditure responses to income shocks that may arise because of conditional cash transfers (Attanasio et al., 2011) and transitory income shocks (Arbelaez et al., 2019; Ganong and Noel, 2019). We also contribute to the literature on household demand (Barnett and Serletis, 2008) and on the role of household heterogeneity (Lewbel and Pendakur, 2009). Last, we contribute to the literature about demand analysis in Colombia (Cortés and Pérez Pérez, 2010).

The rest of the paper proceeds as follows. Section 2 describes the data and provides some descriptive statistics. Section 3 describes our empirical strategy. We show our main results on the impact of shocks on spending in section 4 . We discuss heterogeneous effects and mechanisms in section 5. Section 6 concludes.

\section{Data and Descriptive Statistics}

This section describes the data we use in detail and provide some descriptive statistics about household spending and the prevalence of adverse shocks.

Data source. We use two waves of the Colombian Longitudinal Survey from Universidad de los Andes (Encuesta Longitudinal Colombiana de la Universidad de los Andes, ELCA). The ELCA is a longitudinal survey of about 5,000 urban and 4,500 rural households. We use the survey's 2013 and 2016 waves. This dataset is unique for Colombia, which lacks other longitudinal data sets of this nature for this period.

The survey has separate modules for urban and rural households and collects sociodemographic, labor markets, and spending data. It classifies Colombian households into six economic strata according to income levels. The urban module is representative of the four lowest strata in the urban portion of the country. The rural module is representative of low- and middle-income farm producers in four specific micro-regions that concentrate most of the agricultural production in the country. ${ }^{1}$ The effects of

\footnotetext{
${ }^{1}$ The four micro-regions are: "Atlántica Media", which covers parts of Córdoba and Sucre; "Cundi-
} 
shocks we estimate in section 4 are therefore not representative of the entire rural population (Solon et al., 2015). Because the rural and urban modules represent different population segments, we do not pool them together in our regression models that use survey weights. We also report unweighted estimates to show the robustness of our results.

Income and spending data. The survey collects detailed data on overall household income and income for each household member. It also collects data on spending in several categories. This spending data is collected directly from interviewers using the recall method. As such, spending on certain goods may have some measurement error, particularly for goods purchased at low frequencies (Battistin, 2003).

We harmonize the income and spending data to be comparable across waves. For income, we contrast individual-level with household-level information and real income variation through time for each household and the whole income distribution. For spending, we remove durable expenditures such as furniture and home appliances, education, vehicles, or real estate. We then aggregate the remaining items into nine categories: Food, Alcoholic Beverages and Tobacco, Small Furnishings, Recreation, Health, Personal Services, House Services, Transport and Communication, and Clothing. ${ }^{2}$

Shocks data. The ELCA data includes questions about whether the household experienced shocks in the last three years before being surveyed. Households answer questions about 19 types of shocks of diverse nature, for example: whether a crop failed or whether a member of the household passed away. A household is affected by a health shock if any household member is affected by an accident or illness. ${ }^{3}$

Sample selection. We restrict our analysis to households that we can follow in the second and third waves of the data. ${ }^{4}$

We discard outliers of total household spending. ${ }^{5}$ To control for household member

boyacense", which covers parts of Cundinamarca, Boyacá and Santander; "Eje Cafetero", which covers several municipalities in Risaralda and Quindío; and "Centro-Oriente", which includes municipalities in Tolima and Cundinamarca.

2 The ELCA data has an additional wave for 2010. We do not use this wave because we cannot make income and expenditure from it compatible with income and spending on the other two waves. The questions about different sources of income and expenditure are different in 2010.

3 Table A.1 in the Appendix catalogs the types of shocks available in the data. We classify these shocks into six categories. Arbelaez et al. (2019) also use the shocks data from ELCA and study the shocks' persistence and their effects on household consumption and income.

${ }^{4}$ Attrition between these two waves of data is $4.8 \% ; 6.1 \%$ for the urban sample, and $3.4 \%$ for the rural sample.

${ }^{5}$ We remove the lowest $5 \%$ and the highest $5 \%$ of households in the distribution of total expenditure, as well as those remaining with no positive spending. 
composition changes that may change budget shares, we keep only households whose member composition did not change between waves. A household is in our sample if it did not separate in between the two waves and if none of its members left, arrived, passed away, or were born in between waves. In doing so, we arrive at 2,499 households that maintain the same composition from 2013 to 2016. From these 1,076 are rural, 1,346 are urban, 69 transitioned from rural to urban between waves, and 8 transitioned from urban to rural.

Descriptive statistics. Table 1 shows descriptive statistics of spending and income for urban and rural households. In 2013, urban households received more than twice the monthly income of rural households and spent about 30\% more. By 2016, the income gap narrows, but the expenditure gap remains. The amounts of spending are usually higher for urban households, with a few exceptions. Health spending is higher for rural households in 2013 but declines sharply for 2016. Rural households spend a larger fraction of their total spending on food and smaller fractions on house services, transport, and clothing. The average number of household members is between 3 and 4, with rural households being larger than rural ones. The informality of the household head, which we define as either non-affiliation to social health insurance or not contributing to the pension system, is also higher in rural households. Although the proportion of urban households with an informal head remained constant between 2013 and 2016, the informal rural households' share fell almost by half, from $87 \%$ in 2013 to $55 \%$ in 2016 .

Table 2 shows the percentage of households who experienced negative health shocks. In $2013,26 \%$ of urban households and $24 \%$ of rural households in our sample experienced health shocks. In 2016, the percentage of urban households affected by health shocks slightly decreased, but the percentage of rural households affected increased to $35 \%$. The frequency of shocks is higher for small urban and large rural households. Many agricultural households experience shocks during 2011-2013, but this share falls to about half for 2014-2016. ${ }^{6}$

Table 3 compares budget shares among households that experienced and did not experience health shocks. The differences are substantial for some spending categories. The food budget share is about nine pp lower for rural households experiencing health shocks and is large in standardized terms. In contrast, the food budget shares for shock and non-shock urban households are similar. Urban households with health shocks

\footnotetext{
${ }^{6}$ Appendix table A.2 shows the incidence of other types of shocks.
} 
Table 1: Descriptive Statistics

\begin{tabular}{l|cc|cc} 
& \multicolumn{2}{c}{2013} & \multicolumn{2}{c}{2016} \\
\cline { 2 - 5 } & Urban & Rural & Urban & Rural \\
\hline Household income (pesos/month) & 1211854 & 470932 & 1125653 & 526961 \\
Total spending (pesos/month) & 951828 & 608719 & 1075463 & 601038 \\
Number of members & 3.48 & 3.75 & 3.48 & 3.82 \\
Informal household head & 0.51 & 0.87 & 0.53 & 0.55 \\
\hline Spending by Category (pesos/month) & & & & \\
Food & 461441 & 306271 & 520280 & 394636 \\
Alcoholic beverages and tobacco & 9632 & 13284 & 15868 & 9688 \\
Furnishings & 1970 & 1280 & 1618 & 955 \\
Recreation & 28530 & 8168 & 30915 & 3206 \\
Health & 22865 & 76890 & 21444 & 11596 \\
Personal services & 83851 & 56524 & 104756 & 43010 \\
House services & 136024 & 38145 & 123599 & 53701 \\
Transport and communication & 152708 & 81752 & 189664 & 76503 \\
Clothing & 54807 & 26405 & 67319 & 7743 \\
\hline Budget Shares & & & & \\
Food & 0.503 & 0.545 & 0.513 & 0.676 \\
Alcoholic beverages and tobacco & 0.011 & 0.030 & 0.013 & 0.015 \\
Furnishings & 0.002 & 0.003 & 0.001 & 0.002 \\
Recreation & 0.026 & 0.011 & 0.023 & 0.005 \\
Health & 0.022 & 0.099 & 0.018 & 0.017 \\
Personal services & 0.086 & 0.086 & 0.094 & 0.071 \\
House services & 0.151 & 0.066 & 0.120 & 0.085 \\
Transport and communication & 0.151 & 0.124 & 0.164 & 0.117 \\
Clothing & 0.049 & 0.037 & 0.053 & 0.012 \\
\hline & & & &
\end{tabular}

Monetary amounts are monthly averages by household. Colombian pesos of 2008, deflated using the national yearly consumer price index. Statistics are for the estimation sample of 2499 households, using the average of the survey weights for 2013 and 2016 by household. "Informal household head" is defined as 0 if the household head is affiliated to health insurance and if they contribute to the pension system, and 1 in any other case. Source: ELCA. 
Table 2: Incidence of Adverse Health Shocks

\begin{tabular}{l|ccc|ccc|c}
\hline & Urban & $\begin{array}{r}2013 \\
\text { Rural }\end{array}$ & Overall & Urban & Rural & Overall & $\begin{array}{c}\text { 2013-2016 } \\
\text { Overall }\end{array}$ \\
\hline All households & 0.26 & 0.24 & 0.26 & 0.24 & 0.35 & 0.24 & 0.25 \\
\hline 3 members or less & 0.27 & 0.42 & 0.27 & 0.25 & 0.25 & 0.25 & 0.26 \\
4 members or more & 0.26 & 0.11 & 0.26 & 0.24 & 0.41 & 0.24 & 0.25 \\
\hline Formal household head & 0.27 & 0.05 & 0.27 & 0.22 & 0.34 & 0.22 & 0.25 \\
Informal household head & 0.25 & 0.27 & 0.25 & 0.27 & 0.36 & 0.27 & 0.26 \\
\hline Not in CCT program & 0.26 & 0.23 & 0.26 & 0.24 & 0.47 & 0.24 & 0.25 \\
Is in CCT program & 0.28 & 0.24 & 0.28 & 0.26 & 0.14 & 0.26 & 0.27 \\
\hline No social capital & 0.25 & 0.25 & 0.25 & 0.24 & 0.35 & 0.24 & 0.24 \\
Has social capital & 0.32 & 0.19 & 0.32 & 0.27 & 0.32 & 0.27 & 0.30 \\
\hline Unemployed & 0.22 & 0.04 & 0.22 & 0.30 & 0.09 & 0.30 & 0.26 \\
Employed & 0.27 & 0.27 & 0.27 & 0.23 & 0.37 & 0.24 & 0.25 \\
\hline Unemployed & 0.22 & 0.04 & 0.22 & 0.30 & 0.09 & 0.30 & 0.26 \\
Works with contract & 0.27 & 0.07 & 0.27 & 0.23 & 0.37 & 0.24 & 0.25 \\
Works without contract & 0.27 & 0.31 & 0.27 & 0.23 & 0.38 & 0.23 & 0.25 \\
\hline Unemployed & 0.22 & 0.04 & 0.22 & 0.30 & 0.09 & 0.30 & 0.26 \\
Other primary-secondary sectors & 0.26 & 0.19 & 0.26 & 0.25 & 0.88 & 0.25 & 0.26 \\
Agriculture & 0.33 & 0.24 & 0.33 & 0.17 & 0.32 & 0.18 & 0.27 \\
Wholesaling and retailing & 0.27 & 0.48 & 0.27 & 0.18 & 0.09 & 0.18 & 0.23 \\
Other tertiary sector & 0.26 & 0.20 & 0.26 & 0.26 & 0.07 & 0.26 & 0.26 \\
\hline
\end{tabular}

A household is affected by a health shock if any household member is affected by an accident or illness in the last three years. Informal households are those whose household head is either unaffiliated to social health insurance, or does not contribute to the pension system. The conditional cash transfer program is called Familias en Acción, the main program of its kind in Colombia. A household has social capital if its household head takes part in local groups or organizations of any kind, like political parties, guilds, sports clubs, etc. Labor market variables are calculated always on the household head. "Works with contract" includes households whose head has a verbal contract or a written one. "Other primary and secondary sectors" includes mining, manufacture, construction, and water treatment. "Other tertiary sector" includes hotels, restaurants, public service, education, communication, health services, management, science, art, and other industries not previously classified. Source: ELCA. 
have around a two pp larger share of health expenditure relative to their unaffected counterparts. Rural households have a nine pp higher share. Across the board, rural households tend to reduce spending in non-health categories in response to the shock in a larger magnitude than urban households.

\section{Empirical Strategy}

We estimate the effects of adverse health shocks on spending in different categories by estimating the households' demand for goods in each category and allowing the shocks to shift these demand curves. We estimate the health shock effects by comparing households who experience them to those who do not. We describe the specification, the identification strategy, and the estimation below.

Demand specification. We model household spending in each category of goods as a function of prices, income, and demographics, in line with the literature on demand estimation (Barnett and Serletis, 2008). We guide our estimation from a quadratic demand function with time and household fixed effects:

$$
s_{g h t}=\beta_{0}+P_{g h t}^{\prime} \boldsymbol{\beta}_{\mathbf{P}}+\beta_{x} \ln x_{h t}+\beta_{x^{2}} \ln x_{h t}^{2}+Z_{h t}^{\prime} \gamma+\delta_{h}+\delta_{t}+\varepsilon_{g h t} .
$$

Here, $s_{g h t} \equiv \frac{X_{g h t}}{X_{h t}}$ is the budget share for good category $g$ in household $h$ at time $t$. Demand is linear in the logarithm of prices for good $g$ faced by the household, $P_{g h t}^{\prime}=$ $\left(P_{1 h t}, P_{2 h t}, \ldots, P_{G h t}\right)$. It is quadratic on total household expenditure $X_{h t}$. Additional variables $Z_{h t}$ can shift the level of demand. The variables $\delta_{h}$ and $\delta_{t}$ are household and time fixed-effects, respectively, and $\varepsilon_{g h t}$ is an error term.

This baseline specification is a reduced-form of demand functions from a quadratic almost ideal demand system (Banks et al., 1997). We allow demographics to shift demand linearly as in Pollak and Wales (1981). We also allow for household-level taste heterogeneity through the household fixed effects $\delta_{i}$ (Lecocq and Robin, 2015). ${ }^{7}$

Estimation issues. We cannot estimate equation (1) directly because we lack price data. Instead, we follow Attanasio et al. (2011) and estimate a separate equation for each good category $g$ allowing for heterogeneous trends across regions. These heterogeneous trends capture regional differences in the evolution of prices. The household

\footnotetext{
${ }^{7}$ In this reduced-form approach, we do not estimate the equations for each good in a system of demand functions, neither do we allow for the error terms $\varepsilon_{g h t}$ to be correlated across goods. Seemingunrelated-regressions estimation of these equations would yield the same point estimates because the right-hand-side variables are the same.
} 
Table 3: Average Budget Shares / Health Shock vs. No Health Shock

\begin{tabular}{ll|cc|c|c} 
Budget share & & Shock & No shock & Diff. & Std. diff. \\
\hline \multirow{3}{*}{ Food } & Urban & 0.498 & 0.511 & -0.013 & -0.066 \\
& Rural & 0.555 & 0.646 & -0.091 & -0.402 \\
& Overall & 0.498 & 0.512 & -0.014 & -0.070 \\
\hline \multirow{2}{*}{ Alcoholic beverages } & Urban & 0.011 & 0.012 & -0.001 & -0.026 \\
and tobacco & Rural & 0.010 & 0.026 & -0.016 & -0.254 \\
& Overall & 0.011 & 0.012 & -0.001 & -0.026 \\
\hline \multirow{3}{*}{ Furnishings } & Urban & 0.002 & 0.002 & 0.000 & 0.000 \\
& Rural & 0.001 & 0.002 & -0.001 & -0.156 \\
& Overall & 0.002 & 0.002 & 0.000 & 0.000 \\
\hline \multirow{3}{*}{ Recreation } & Urban & 0.028 & 0.023 & 0.005 & 0.078 \\
& Rural & 0.004 & 0.009 & -0.005 & -0.191 \\
& Overall & 0.028 & 0.023 & 0.005 & 0.078 \\
\hline \multirow{3}{*}{ Health } & Urban & 0.034 & 0.016 & 0.018 & 0.250 \\
& Rural & 0.116 & 0.026 & 0.090 & 0.434 \\
& Overall & 0.034 & 0.016 & 0.018 & 0.245 \\
\hline \multirow{3}{*}{ Personal services } & Urban & 0.086 & 0.091 & -0.005 & -0.064 \\
& Rural & 0.062 & 0.084 & -0.022 & -0.362 \\
& Overall & 0.086 & 0.091 & -0.005 & -0.064 \\
\hline \multirow{3}{*}{ House services } & Urban & 0.136 & 0.135 & 0.001 & 0.009 \\
& Rural & 0.115 & 0.061 & 0.054 & 0.566 \\
\hline \multirow{2}{*}{ Transport and } & Overall & 0.136 & 0.135 & 0.001 & 0.009 \\
\hline \multirow{2}{*}{ Communication } & Urban & 0.161 & 0.157 & 0.004 & 0.027 \\
& Rural & 0.129 & 0.116 & 0.013 & 0.102 \\
& Overall & 0.161 & 0.156 & 0.005 & 0.033 \\
\hline & Urban & 0.044 & 0.053 & -0.009 & -0.098 \\
& Rural & 0.007 & 0.030 & -0.023 & -0.405 \\
& Overall & 0.044 & 0.053 & -0.009 & -0.098 \\
\hline & & & & &
\end{tabular}

The standardized difference is calculated as $\left(\bar{x}_{1}-\bar{x}_{0}\right) / \sqrt{\sigma_{1}^{2}+\sigma_{0}^{2}}$, where $\sigma_{i}^{2}$ is the variance of each budget share in each group $i$. 
fixed effects absorb any cross-sectional variation in $Z_{h t}$. To allow for a flexible role of demographics in determining expenditure evolution, we allow for differential time trends interacted with demographics in the first period. We control for the education level of the household head in 2013. To account for the spatial correlation of prices and other unobservables at the municipality level, we cluster our standard errors by municipality.

An additional issue with equation (1) is the presence of division bias because $X_{h t}$ appears both on the left- and right-hand sides. While this is a pervasive problem in cross-sectional demand estimation, we note that it is likely to be much less of an issue in the panel setting. On the cross-section, division bias would imply a negative mechanical correlation between $X_{h t}$ and $\varepsilon_{g h t}$ because households with larger expenditures would have smaller budget shares. However, this cross-sectional effect is addressed by the fixed effects, $\delta_{h}$. For an individual household over time, budget shares would be mechanically lower if total expenditure increases. The time dummies $\delta_{t}$ and the differential trends by demographics address this mechanical effect. Any remaining division bias would come from the differential evolution of expenditure not addressed by these controls. Nevertheless, in the appendix, we report estimates instrumenting total household expenditure with lagged total household income as is customary in this literature (Barnett and Serletis, 2008; Attanasio et al., 2011). Our results are qualitatively similar, although, as shown in the next section, lagged household income is not a strong instrument in this panel setting (Lecocq and Robin, 2015).

Addressing these issues with prices and demographics, and considering that we only use two waves of data, our specification for demand in the absence of shocks is:

$$
\begin{aligned}
s_{g h t} & =\beta_{0}+\sum_{s} \delta_{r(h)} 1(r(h)=s) 1(t=2016)+\beta_{X} \ln X_{h t}+\beta_{X^{2}} \ln X_{h t}^{2} \\
& +Z_{h, 2013}^{\prime} 1(t=2016) \gamma+\delta_{h}+\delta_{t}+\varepsilon_{g h t} .
\end{aligned}
$$

Here, $1(r(h)=s)$ is a region indicator, and $1(t=2016)$ equals one for the second wave of data and zero otherwise.

Effect of shocks. We allow adverse shocks in the previous three years to shift demand as covariates $Z$ in equation (2): 


$$
\begin{aligned}
s_{g h t} & =\beta_{0}+\sum_{s} \delta_{r(h)} 1(r(h)=s) 1(t=2016)+\beta_{X} \ln X_{h t}+\beta_{X^{2}} \ln X_{h t}^{2} \\
& +\theta \text { Health Shock } \text { Sh,t-1 }+ \text { Shocks }_{h, t-1}^{\prime} \gamma_{\text {Shocks }}+Z_{h t}^{\prime} 1(t=2016) \boldsymbol{\gamma}+\delta_{h}+\delta_{t}+\varepsilon_{g h t} .
\end{aligned}
$$

In this regression, Health Shock $_{h, t-1}$ is one if a household experienced an adverse health shock in the previous three years, and zero otherwise. The coefficient of interest $\theta$ measures how demand shifts in the presence of health shocks. The vector Shocks $s_{h, t-1}$ contains indicator variables for shocks in each of the other shock categories. The vector of coefficients $\gamma_{\text {Shocks }}$ captures the effect of these other shocks. Since all the shocks are idiosyncratic and specific to each household, we do not expect them to alter prices through general equilibrium effects.

Allowing shocks to enter the demand curve linearly amounts to assuming that these shocks shift Engel curves up or down but do not change the price elasticities nor the income elasticities of demand. Moreover, it assumes that the shocks impact demand beyond their effect on total expenditure. To show evidence supporting this specification, we estimate unconditional non-parametric Engel curves for households that experience and do not experience health shocks. We do this through local polynomial regression. The visual evidence on shifts of these demand curves helps to validate our linear specification in equation (3).

While from a demand theory point-of-view equation (3) is a standard demand specification with covariates, conditioning on total expenditure to evaluate the effect of shocks means that we are conditioning on an outcome. Such conditioning is a source of concern. However, in the appendix, we show that when we instrument total household expenditure with lagged household income, which is unaffected by shocks, our estimates remain similar. We also indicate no substantial differences in the total expenditure responses to shocks between urban and rural households.

Heterogeneous responses. We examine different spending responses to health shocks for households with different characteristics by interacting the shock indicators in equation (3) with several household characteristics. We consider different responses for rural and urban households, for households with heads working in the formal or informal sectors, households with access to safety nets, and households whose heads work in different economic sectors. 


\section{Effects of Health Shocks on Spending}

In this section, we outline our main results. We show that health shocks affect food and health budget shares differently across urban and rural households. Conditional on total expenditure, rural households adjust their food and health spending more sharply in response to shocks. Formal households, households with social capital, and whose heads have jobs with contracts, are more likely to adjust to the health shock without substantial spending changes.

Overall effect of health shocks on food and health expenditure. Table 4 shows the coefficients on health shocks from the estimation of equation (3). We find significant food and health spending changes in response to the health shocks with stark differences across urban and rural households. Our regressions on panel 2 with controls and region-specific trends show that urban households decrease their food budget share by $1.8 \mathrm{pp}$ conditional on total spending. They increase their health budget share by 1.2 pp Rural households adjust their spending more heavily. Their health spending share goes up by about five pp, and their food spending share decreases by three pp.

Several channels may be at work behind this finding. Rural households may be less insured than urban ones and unable to smooth the health shock -and incur additional health spending- without reducing their spending in other categories. This reduced insurance may be due to several characteristics, such as labor informality. We turn to these mechanisms in section 5 .

We show three pieces of additional evidence on the responsiveness of food and health spending to shocks in the appendix. First, we note that we have restricted our attention to food and health spending. In appendix table A.7, we show results for all spending categories. Urban households seem to increase their spending on personal care by a substantial fraction in response to the health shock and seem to steer away from recreation and alcohol purchases. There are not many changes in other budget shares for rural households except for transport. An increase makes sense if rural households are far from health service providers. They also seem to decrease their share of spending on clothing. Food and health spending are by far the most reactive for rural households, and we continue to focus on them going forward.

We also show the response of food and health spending to other types of shocks in Appendix table A.3, which includes full estimation results for table 4. Spending seems to be most responsive to health shocks, although some other shocks may also induce adjustments. Family shocks tend to reduce food spending in rural households 
Table 4: Effect of Health Shocks on Food and Health Spending

\begin{tabular}{|c|c|c|c|c|}
\hline & \multicolumn{2}{|c|}{ Urban } & \multicolumn{2}{|c|}{ Rural } \\
\hline & Food & Health & Food & Health \\
\hline \multicolumn{5}{|c|}{ Panel 1: No controls nor region-specific trends } \\
\hline Health shock & $\begin{array}{c}-0.020^{* * *} \\
(0.005)\end{array}$ & $\begin{array}{c}0.013^{* * *} \\
(0.002)\end{array}$ & $\begin{array}{l}-0.053 \\
(0.040)\end{array}$ & $\begin{array}{c}0.069 \\
(0.045)\end{array}$ \\
\hline Observations & 2769 & 2769 & 2229 & 2229 \\
\hline $\mathrm{R}^{2}$ & 0.049 & 0.054 & 0.416 & 0.330 \\
\hline Mean dep. var. & 0.536 & 0.023 & 0.622 & 0.035 \\
\hline Household F. E. & $\checkmark$ & $\checkmark$ & $\checkmark$ & $\checkmark$ \\
\hline Time effects & $\checkmark$ & $\checkmark$ & $\checkmark$ & $\checkmark$ \\
\hline Region Trends & & & & \\
\hline
\end{tabular}

Panel 2: Controls and region-specific trends

\begin{tabular}{lcccc} 
Health shock & $\begin{array}{c}-0.018^{* * *} \\
(0.005)\end{array}$ & $\begin{array}{c}0.012^{* * *} \\
(0.002)\end{array}$ & $\begin{array}{c}-0.029^{*} \\
(0.015)\end{array}$ & $\begin{array}{c}0.050^{* *} \\
(0.021)\end{array}$ \\
\hline Observations & 2769 & 2769 & 2229 & 2229 \\
$\mathrm{R}^{2}$ & 0.062 & 0.067 & 0.578 & 0.485 \\
Mean dep. var. & 0.536 & 0.023 & 0.622 & 0.035 \\
Household F. E. & $\checkmark$ & $\checkmark$ & $\checkmark$ & $\checkmark$ \\
Time effects & $\checkmark$ & $\checkmark$ & $\checkmark$ & $\checkmark$ \\
Region Trends & $\checkmark$ & $\checkmark$ & $\checkmark$ & $\checkmark$ \\
\hline
\end{tabular}

The table shows the coefficients on the health shock from estimates of equation (3). Standard errors clustered by municipality in parentheses. Panel 1 shows regressions without any controls. Panel 2 includes region-specific trends and the education level of the household head in 2013, interacted with the trend. We also control for all the other shocks in Appendix Table A.1, total spending, and total spending squared in both panels. $\mathrm{p}<0.1,{ }^{*} ; \mathrm{p}<0.05, * * *: \mathrm{p}<0.01$. 
and increase it in urban ones.

Additionally, we show in appendix table A.5 the unweighted estimation of equation (3). We find that the conclusions derived from table 4 are robust to this change in the estimation procedure, slightly affecting the magnitude of some coefficients. With controls, the unweighted estimates for the effect of a health shock in the share of food spending are larger for urban households and smaller for rural households when compared to the weighted estimates, but the inequality between urban and rural remains.

Last, we show that our results in table 4 are not driven by division bias or by bias from including total household spending on the right-hand side. Appendix table A.4 shows estimates instrumenting total spending and total spending squared with lagged income and lagged income squared. Qualitatively, our results show similar magnitudes to those of table 4. However, income as an instrument does not seem to perform as well in this panel setting (Lecocq and Robin, 2015). As such, our IV estimates are substantially noisy.

Effects on other expenditure categories and total spending. Although our focus is on food and health spending, we also estimate the spending response in other budget categories and on total spending. Appendix figure A.1 shows the predicted change in average budget shares stemming from a health shock. We build these predicted shares using estimates of equation (3) for each spending category. AS shown in our results on table 4 , food and health spending show significant changes in rural and urban households. The increase in health spending may also be financed with reductions in spending in other categories. However, the budget share changes in other spending are mostly not statistically significant, with the exception of a reduction of clothing expenditure for rural households.

The small reductions in other spending besides food, imply that households may have to increase their total spending in response to health shocks. In Appendix table A.8, we estimate a regression analogous to that of equation (3), using log total spending as our dependent variable (and removing it from the control set). We show that rural households increase their total spending by about 6 p.p. in response to the health shock. In contrast, urban households have a not statistically significant increase in spending, but the estimate is noisy.

Engel curves. To show more evidence on the role of health shocks in shifting demand for food and health goods, and to justify our regression specification; we show non-parametric evidence of the adjustments of demand to health shocks. We estimate non-parametric Engel curves through local polynomial regression and obtain separate 
estimates for health-shock-affected and unaffected households. ${ }^{8}$

Figures 1 and 2 show Engel curves for food. These are approximately linear for urban households spending over 300.000 pesos a month and for all rural households. For both waves, and urban and rural households, the estimated curves for households affected by the health shock are below those of households unaffected by it. The differences are larger for mid-spending rural households.

Figure 1: Food Engel Curves, for Urban Households with/without a Health Shock.

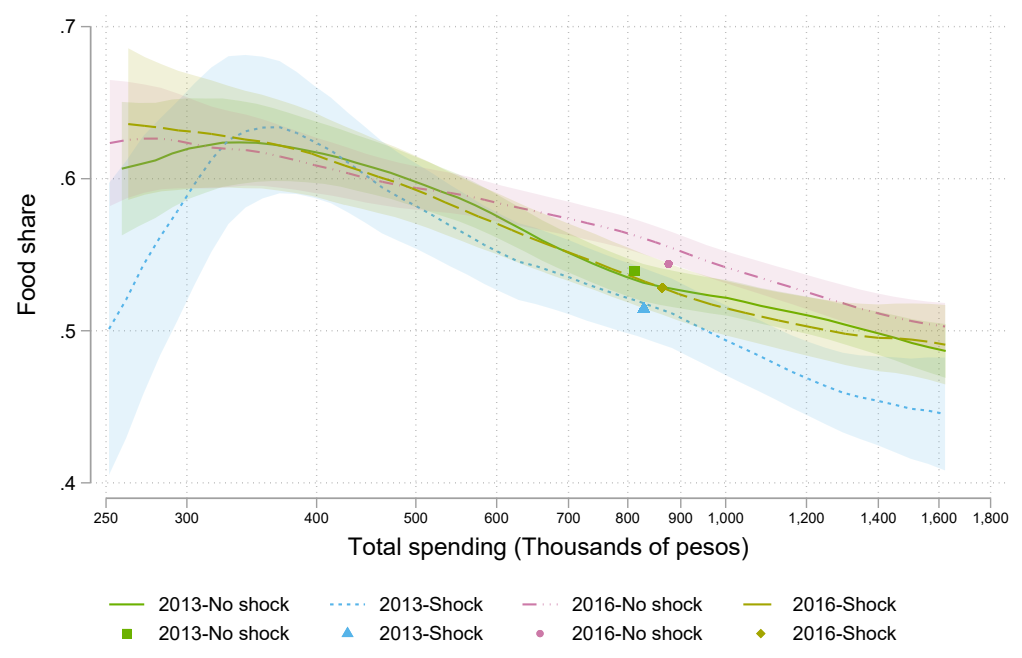

Local polynomials estimated using a triangular kernel, where the bandwidths are chosen by the rule of thumb of minimizing the conditional weighted mean integrated squared error. Points represent the average household in each of the four samples.

Figures 3 and 4 show the equivalent estimates for the health Engel curve. Once again, the Engel curves are approximately linear except for low spending urban households. The Engel curves of shock households are above that of unaffected households.

The figure for rural households shows some evidence of a change in slope between the curve for unaffected households and affected ones. This slope change would invalidate our specification in equation (3), which only allows for level shifts in response to shocks. In Appendix table A.6, we estimate specifications that enable the health shock to change the slope of the Engel curves. Our estimates for the marginal effect of the health shock on the average household's spending shares are virtually identical to those of table 4 .

\footnotetext{
${ }^{8}$ Our estimates are not conditional to other shocks. Given the low impact of different types of shocks on demand shown in Appendix table A.3, the conditional and unconditional Engel curves are similar.
} 
Figure 2: Food Engel Curves, for Rural Households with/without a Health Shock.

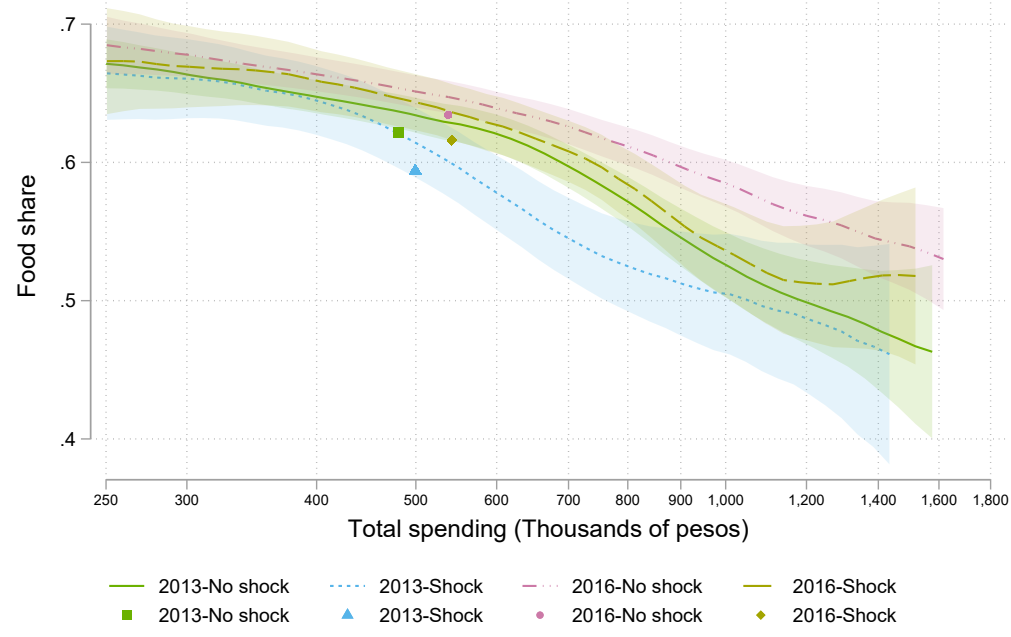

Local polynomials estimated using a triangular kernel, where the bandwidths are chosen by the rule of thumb of minimizing the conditional weighted mean integrated squared error. Points represent the average household in each of the four samples.

Figure 3: Health Engel Curves, for Urban Households with/without a Health Shock.

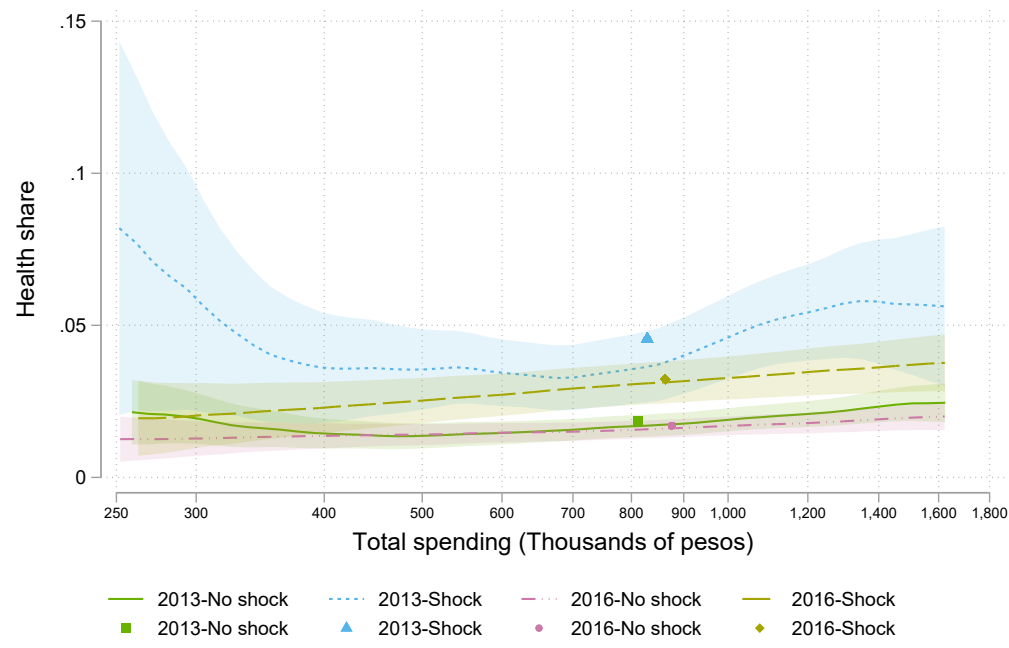

Local polynomials estimated using a triangular kernel, where the bandwidths are chosen by the rule of thumb of minimizing the conditional weighted mean integrated squared error. Points represent the average household in each of the four samples. 
Figure 4: Health Engel Curves, for Rural Households with/without a Health Shock.

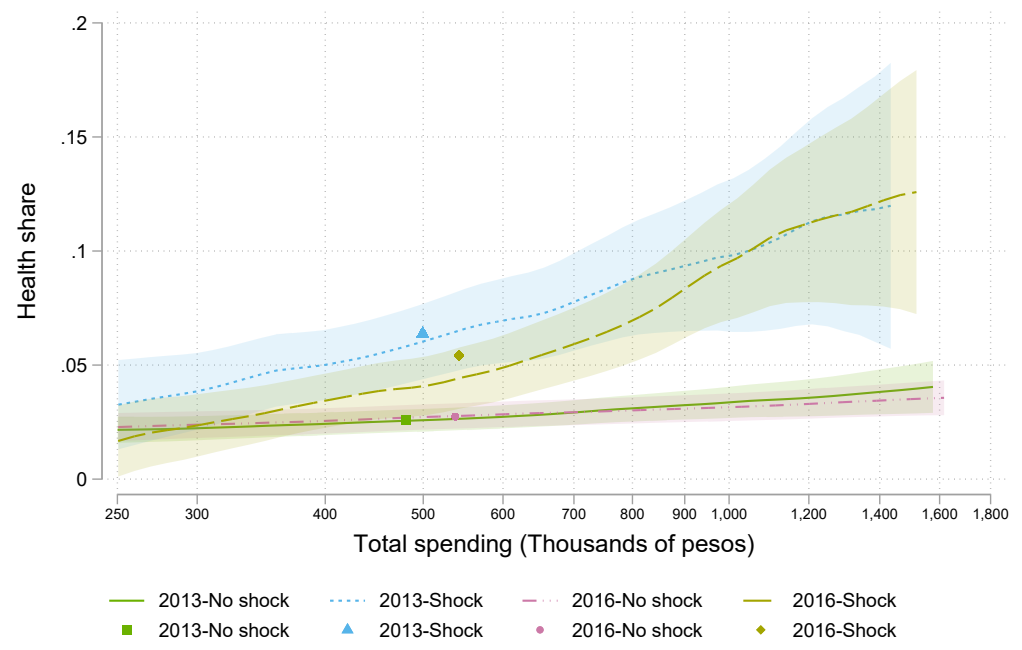

Local polynomials estimated using a triangular kernel, where the bandwidths are chosen by the rule of thumb of minimizing the conditional weighted mean integrated squared error. Points represent the average household in each of the four samples.

\section{$5 \quad$ Heterogeneous Effects}

This section examines heterogeneous responses of food and health spending to shocks by types of households. We highlight the role of informality and insurance in shaping the spending response to health shocks. Households whose heads work in the formal sector and who have access to insurance through social capital are more able to smooth the shock and reduce their spending adjustments.

Figure 5 shows estimates of the response of food spending to health shocks obtained from interacting the health shock dummy with household characteristics. Overall, as expected from table 4, the adjustments for rural households are more extensive. This pattern reappears in figure 6 , which shows that health spending increases more in rural households across groups. We now turn to each one of the categories driving heterogeneity in the spending response.

Household size. Larger households may have more trouble adjusting food spending because of broader caloric needs at the household level. At the same time, larger families may have the potential of sending more members to the labor force in response to a shock (Wagstaff, 2007). We find that small households reduce their food spending by around three pp in response to the health shock, whereas large households with 


\section{Figure 5: Heterogeneous Effects of a Health Shock in the Share of Food Spending}

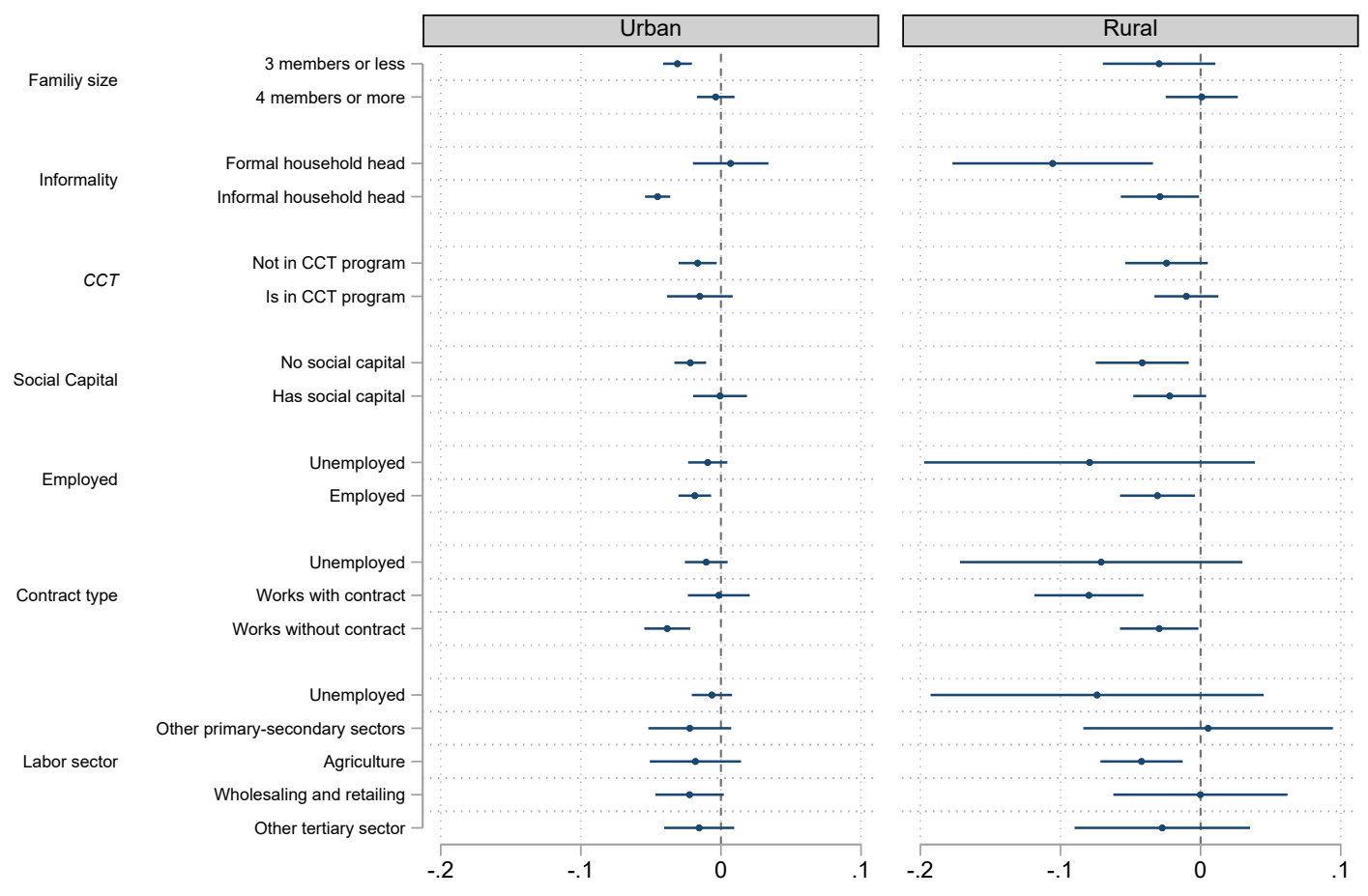

The dots are point estimates of the effect of a health shock on food spending for different household characteristics. Estimates are obtained from equation 3, interacting the health shock dummy with household characteristics. Horizontal bars are 95\% confidence intervals, from standard errors clustered by municipality. Informal households are those whose household head is either unaffiliated to social health insurance, or does not contribute to the pension system. The conditional cash transfer program is called Familias en Acción, the main program of its kind in Colombia. A household has social capital if its household head takes part in local groups or organizations of any kind, like political parties, guilds, sports clubs, etc. Labor market variables are calculated always on the household head. "Works with contract" includes households whose head has a verbal contract or a written one. "Other primary and secondary sectors" includes mining, manufacture, construction, and water treatment. "Other tertiary sector" includes hotels, restaurants, public service, education, communication, health services, management, science, art, and other industries not previously classified. 


\section{Figure 6: Heterogeneous Effects of a Health Shock in the Share of Health Spending}

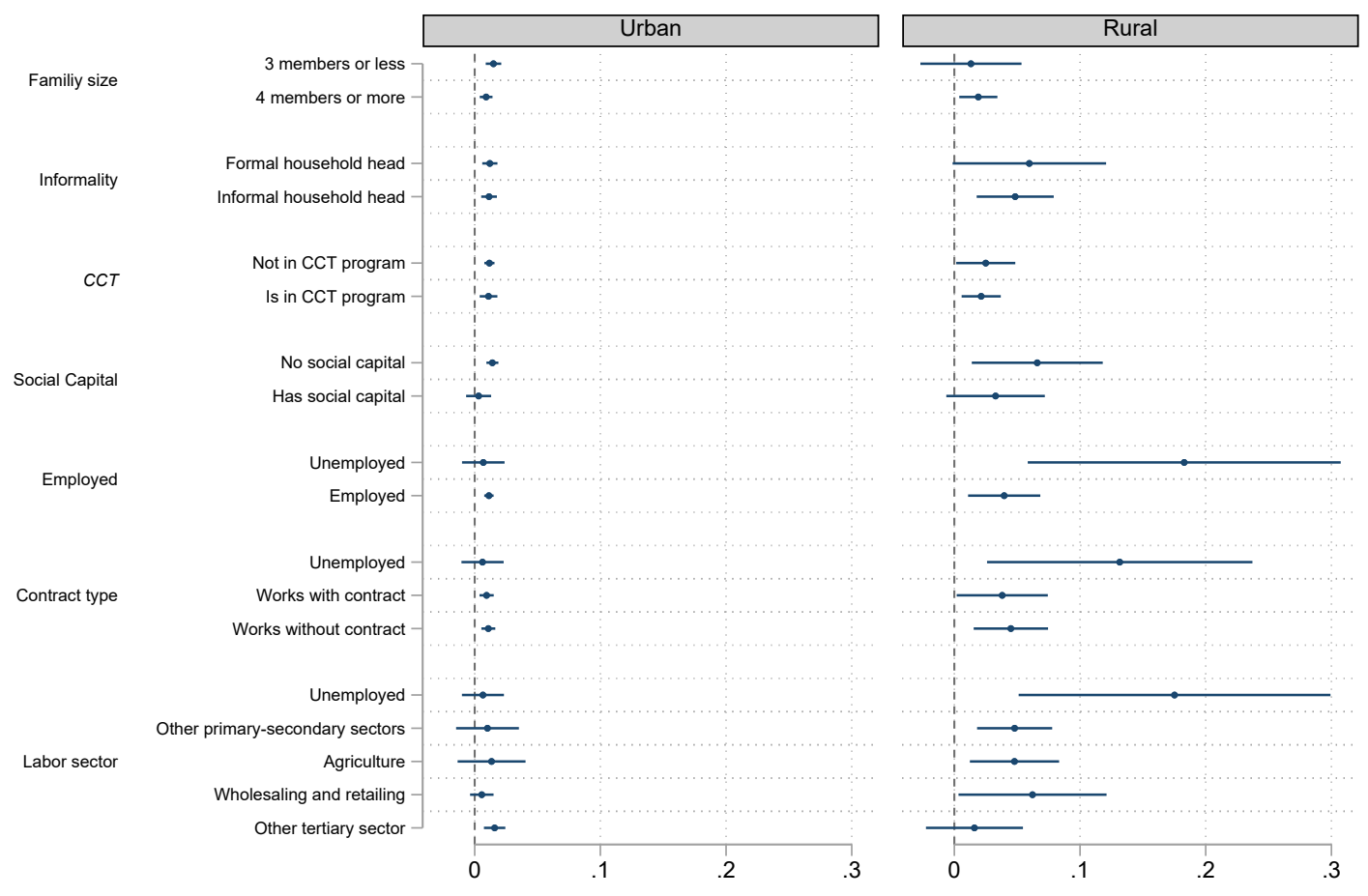

The dots are point estimates of the effect of a health shock on health spending for different household characteristics. Estimates are obtained from equation 3, interacting the health shock dummy with household characteristics. Horizontal bars are 95\% confidence intervals, from standard errors clustered by municipality. Informal households are those whose household head is either unaffiliated to social health insurance, or does not contribute to the pension system. The conditional cash transfer program is called Familias en Acción, the main program of its kind in Colombia. A household has social capital if its household head takes part in local groups or organizations of any kind, like political parties, guilds, sports clubs, etc. Labor market variables are calculated always on the household head. "Works with contract" includes households whose head has a verbal contract or a written one. "Other primary and secondary sectors" includes mining, manufacture, construction, and water treatment. "Other tertiary sector" includes hotels, restaurants, public service, education, communication, health services, management, science, art, and other industries not previously classified. 
four or more household members do not adjust food spending. The different effect is independent of whether the household is urban o rural, although the reduction for small rural households is not significant at the $95 \%$ level. The increases in health spending are more considerable for small urban households and large rural households. The labor supply margin may be at play for these large rural households who can increase their health spending by a larger fraction without reducing their health spending.

Informality. We classify households as informal if their household head is either unaffiliated to employer-provided health insurance or does not make contributions to the pension system. We find that labor informality plays a large role in shaping the food spending reaction to health shocks in urban households. The increase in health spending is similar for formal and informal urban households, but only informal households decrease their food spending. Such heterogeneity is not necessarily a mechanical effect of access to health insurance since informal households may still have insurance through the public health system. The food share falls by about four pp for informal urban households. Rural households paint a different picture. Formal rural households have large food spending decreases in response to the health shock. However, only a small share of rural households is formal, so that this result may be due to the small sample size.

CCTs and social capital. We turn to informal sources of insurance and insurance coming from other sources of income. We do not find large differences in the food spending response of urban households according to whether they receive transfers from Familias en Acción, Colombia's flagship conditional cash transfers program. Rural families who receive transfers do not reduce their food spending in response to the health shock in a statistically significant magnitude. However, the estimates are noisy and do not point to a big difference between transfer-receiving and non-transfer receiving rural households. Their health spending increases are also similar, even among urban households.

Households may also insure themselves by risk-sharing. ${ }^{9}$ This risk-sharing may be easier if households belong to informal networks. We create a dummy variable for social capital that is active if the household head participates in local groups or organizations of any kind, such as political parties, guilds, or sports clubs.

\footnotetext{
${ }^{9}$ For example, Acquah and Dahal (2018) study the Rotating Savings and Credit Associations in Indonesia. These are informal financial institutions used to get access to credit or increase savings and are formed by groups of people such as neighbors, relatives, and friends. They find evidence of risk-sharing across members of the same associations.
} 
We only find statistically significant decreases in food spending in response to the health shock in households without social capital. The food spending response of urban households with social capital is close to zero. For rural households, the food spending decrease without social capital is almost twice as large as that of households with social capital.

The results for health spending follow the same pattern. Only households without social capital increase their health budget share in response to the health shock. The estimate for urban households is close to zero, and the estimate for social capital rural households is half of that for non-social-capital ones.

These results point to a substantial role of social networks and risk-sharing to mitigate health shocks. Other studies have found evidence of smoothing through risksharing (Attanasio and Székely, 2004; Genoni, 2012; Gertler and Gruber, 2002; Sparrow et al., 2014). We highlight that access to social capital eliminates the need to reduce food spending when illnesses or accidents strike.

Work status, contract, and industry. The last set of variables we explore pertains to the labor market characteristics of the households.

Unsurprisingly, it seems to be harder to smooth consumption in response to the health shock for households whose heads are unemployed. This difficulty is particularly noticeable for rural households. Their food budget share decrease is about three times that of employed rural households, and their health spending share increase is about four times larger. The urban households' case is surprising, with more extensive adjustments for employed households.

Households whose heads work without a contract, a small share of urban households, reduce their food spending in response to the health shock, while those with heads with a contract job do not. This distinction is somewhat meaningless for rural households since most of them work without contracts.

Last, when we turn to the role of the industry where the household head is employed, we do not see substantial differences for urban households. For rural families, workers in the primary sector have the most extensive health spending increase in response to the shock. The workers may be more prone to be informal or less insured. 


\section{Concluding Remarks}

Health adverse shocks cause complex changes in households' spending behavior. We look at how households in Colombia behave when they face such a shock. This case is fascinating because Colombia has a comprehensive health insurance system that covers almost the entire population. Despite that, we show that such a system does not provide complete insurance. In particular, we find that when facing of a negative health shock, on average, households substitute food expenditures with health expenditures, i.e., they substitute future health for present health. Such a substitution might play a critical role in disadvantaged households' development and in the likelihood of overcoming poverty.

We show that increases in health expenditures (and reductions in food expenditures) are larger for rural households. Formality (paying for health insurance and pension) attenuates this trade-off in urban households but not in rural households. Interestingly, cash transfers programs and social capital provide insurance for families to deal with such a shock. On top of that, the household headÂ's labor status plays a role in the household's ability to attenuate substitution. Beyond informality, unemployed workers and workers without labor contracts are more vulnerable to adverse health shocks.

To the extent that improving present health has the cost of deteriorating future health, informality-reducing policies appear to be critical (especially in the rural sector) for households to escape from poverty traps. Our findings provide an additional mechanism on how social insurance programs might help to alleviate poverty conditions. Further research on this topic is needed.

\section{References}

Acquah, Joseph Kofi and Roshani Dahal (2018), "ROSCAs as Lenders of Last Resort After Financial Crises: Lessons from Indonesia." Journal of International Development, 30, 1223-1239.

Arbelaez, Mateo, Leopoldo Fergusson, and Andres Zambrano (2019), "Endogenous Persistent Shocks and Poverty Traps." Mimeo.

Attanasio, Orazio, Erich Battistin, and Alice Mesnard (2011), "Food and Cash Transfers: Evidence from Colombia." The Economic Journal, 122, 92-124. 
Attanasio, Orazio P and Miguel Székely (2004), "Wage Shocks and Consumption Variability in Mexico During the 1990s." Journal of Development Economics, 73, 1-25.

Banks, James, Richard Blundell, and Arthur Lewbel (1997), "Quadratic Engel Curves and Consumer Demand." Review of Economics and Statistics, 79, 527-539.

Barnett, William A and Apostolos Serletis (2008), "Consumer Preferences and Demand Systems." Journal of Econometrics, 147, 210-224.

Battistin, Erich (2003), "Errors in Survey Reports of Consumption Expenditures." Technical report, IFS Working Papers.

Blundell, Richard, Margherita Borella, Jeanne Commault, and Mariacristina De Nardi (2020), "Why does Consumption Fluctuate in Old Age and How Should the Government Insure It?" Technical report, NBER Working Paper 27348.

Cortés, Darwin and Jorge Pérez Pérez (2010), "El Consumo de los Hogares Colombianos, 2006-2007: Estimación de Sistemas de Demanda." Desarrollo y Sociedad, $7-44$.

Deaton, Angus and John Muellbauer (1980), Economics and Consumer Behavior. Cambridge University Press.

Ganong, Peter and Pascal Noel (2019), "Consumer Spending During Unemployment: Positive and Normative Implications." American Economic Review, 109, 2383-2424.

Genoni, Maria Eugenia (2012), "Health Shocks and Consumption Smoothing: Evidence from Indonesia." Economic Development and Cultural Change, 60, 475 - 506.

Gertler, Paul and Jonathan Gruber (2002), "Insuring Consumption Against Illness." American Economic Review, 92, 51-70.

Gertler, Paul, David I Levine, and Enrico Moretti (2009), "Do Microfinance Programs Help Families Insure Consumption Against Illness?" Health Economics, 18, 257-273.

Lecocq, Sébastien and Jean-Marc Robin (2015), "Estimating Almost-ideal Demand Systems with Endogenous Regressors." The Stata Journal, 15, 554-573.

Lewbel, Arthur and Krishna Pendakur (2009), "Tricks with Hicks: The EASI demand system." American Economic Review, 99, 827-63. 
Pollak, Robert A and Terence J Wales (1981), "Demographic Variables in Demand Analysis." Econometrica: Journal of the Econometric Society, 1533-1551.

Solon, Gary, Steven J Haider, and Jeffrey M Wooldridge (2015), "What are We Weighting For?" Journal of Human Resources, 50, 301-316.

Sparrow, Robert, Ellen Van de Poel, Gracia Hadiwidjaja, Athia Yumna, Nila Warda, and Asep Suryahadi (2014), "Coping with the Economic Consequences of Ill Health in Indonesia." Health Economics, 23, 719-728.

Wagstaff, Adam (2007), "The Economic Consequences of Health Shocks: Evidence from Vietnam." Journal of Health Economics, 26, 82-100. 


\section{Appendix}

\section{A Additional Figures and Tables}

Table A.1: Types of Shocks

\begin{tabular}{ll}
\hline \multicolumn{1}{c}{ Individual Shock } & Classification \\
\hline $\begin{array}{l}\text { Death of household head or their spouse } \\
\text { Death of another household member } \\
\text { Divorce }\end{array}$ & Family shock \\
Abandonment of their habitual residence & \\
Arrival of a relative & \\
\hline Accident or illness of any household member & Health shock \\
\hline $\begin{array}{l}\text { Household head lost their job } \\
\text { Household head's spouse lost their job }\end{array}$ & \\
Other member lost their job & Economic shock \\
Bankruptcy of the family business & \\
Loss or reduction of remittances & \\
\hline Loss of farms, ranches or plantations & Farm Income shock \\
Pests or loss of harvest & \\
Loss or death of animals & \\
\hline Theft, fire or destruction of assets & Crime shock \\
Loss of dwelling & \\
Victim of the conflict & Natural disaster shock \\
\hline Floods, mudslides, landslides, avalanches or gales & \\
\hline $\begin{array}{l}\text { Earthquakes } \\
\text { Drought }\end{array}$ & \\
\hline
\end{tabular}

Source: ELCA. 
Figure A.1: Average Predicted Budget Shares for Urban and Rural Households Before and After a Health Shock
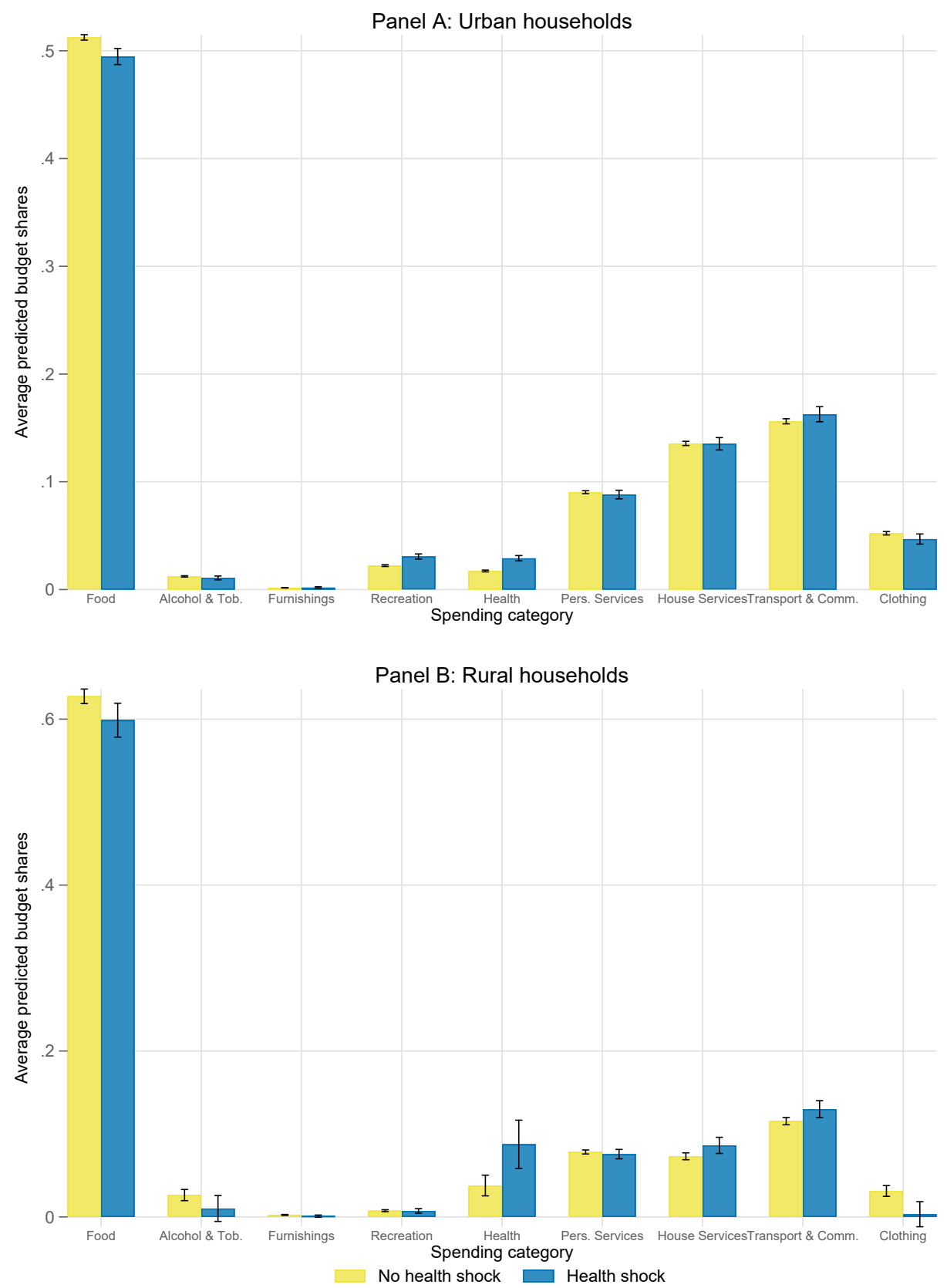

The figure shows average predicted budget shares before and after a health shock, using estimates from equation (3). The black vertical ranges are confidence intervals at the $95 \%$ confidence level. 
Table A.2: Frequency of Shocks

\begin{tabular}{l|ccc|ccc} 
& \multicolumn{3}{|c|}{ Wave 2013 } & \multicolumn{3}{c}{ Wave 2016 } \\
\cline { 2 - 7 } & Urban & Rural & Overall & Urban & Rural & Overall \\
\hline \hline Economic shock & 0.26 & 0.12 & 0.25 & 0.26 & 0.41 & 0.26 \\
Farm Income shock & 0.00 & 0.37 & 0.00 & 0.00 & 0.23 & 0.00 \\
Family shock & 0.19 & 0.28 & 0.19 & 0.04 & 0.00 & 0.04 \\
Natural disaster shock & 0.06 & 0.27 & 0.06 & 0.08 & 0.43 & 0.08 \\
Health shock & 0.26 & 0.24 & 0.26 & 0.24 & 0.35 & 0.24 \\
Crime shock & 0.10 & 0.03 & 0.10 & 0.08 & 0.01 & 0.08 \\
\hline Any shock & 0.57 & 0.64 & 0.57 & 0.52 & 0.83 & 0.52
\end{tabular}

Source: ELCA. 
Table A.3: Effects of All Types of Shocks on Food and Health Spending

\begin{tabular}{|c|c|c|c|c|}
\hline & \multicolumn{2}{|c|}{ Urban } & \multicolumn{2}{|c|}{ Rural } \\
\hline & Food & Health & Food & Health \\
\hline \multicolumn{5}{|c|}{ Panel 1: No controls nor region fixed effects } \\
\hline Economic shock & $\begin{array}{c}-0.001 \\
(0.005)\end{array}$ & $\begin{array}{c}0.001 \\
(0.004)\end{array}$ & $\begin{array}{c}0.052 \\
(0.039)\end{array}$ & $\begin{array}{c}0.035 \\
(0.021)\end{array}$ \\
\hline Farm Income shock & $\begin{array}{c}0.000 \\
(0.000)\end{array}$ & $\begin{array}{c}0.000 \\
(0.000)\end{array}$ & $\begin{array}{c}-0.063^{*} \\
(0.033)\end{array}$ & $\begin{array}{c}0.026 \\
(0.026)\end{array}$ \\
\hline Family shock & $\begin{array}{c}0.023^{* *} \\
(0.009)\end{array}$ & $\begin{array}{l}-0.003 \\
(0.005)\end{array}$ & $\begin{array}{c}-0.163^{*} \\
(0.096)\end{array}$ & $\begin{array}{c}0.139 \\
(0.098)\end{array}$ \\
\hline Natural disaster shock & $\begin{array}{c}0.016 \\
(0.016)\end{array}$ & $\begin{array}{l}-0.010 \\
(0.006)\end{array}$ & $\begin{array}{l}-0.014 \\
(0.029)\end{array}$ & $\begin{array}{l}0.033^{*} \\
(0.019)\end{array}$ \\
\hline Health shock & $\begin{array}{c}-0.020 * * * \\
(0.005)\end{array}$ & $\begin{array}{c}0.013^{* * *} \\
(0.002)\end{array}$ & $\begin{array}{l}-0.053 \\
(0.040)\end{array}$ & $\begin{array}{c}0.069 \\
(0.045)\end{array}$ \\
\hline Crime shock & $\begin{array}{c}-0.004 \\
(0.008)\end{array}$ & $\begin{array}{c}0.007^{*} \\
(0.004)\end{array}$ & $\begin{array}{c}-0.006 \\
(0.021)\end{array}$ & $\begin{array}{c}-0.004 \\
(0.020)\end{array}$ \\
\hline $\ln ($ Spending $)$ & $\begin{array}{c}0.811^{* * *} \\
(0.159)\end{array}$ & $\begin{array}{c}0.028 \\
(0.076)\end{array}$ & $\begin{array}{c}2.061^{* * *} * \\
(0.537)\end{array}$ & $\begin{array}{c}-0.946^{* * *} \\
(0.335)\end{array}$ \\
\hline $\ln (\text { Spending })^{2}$ & $\begin{array}{c}-0.031^{* * *} \\
(0.006)\end{array}$ & $\begin{array}{l}-0.000 \\
(0.003)\end{array}$ & $\begin{array}{c}-0.082^{* * *} \\
(0.021)\end{array}$ & $\begin{array}{c}0.038^{* * *} \\
(0.013)\end{array}$ \\
\hline Observations & 2769 & 2769 & 2229 & 2229 \\
\hline & 0.049 & 0.054 & 0.416 & 0.330 \\
\hline Mean dep. var. & 0.536 & 0.023 & 0.622 & 0.035 \\
\hline \multicolumn{5}{|c|}{ Panel 2: Controls and region fixed effects } \\
\hline Economic shock & $\begin{array}{c}-0.002 \\
(0.006)\end{array}$ & $\begin{array}{c}0.001 \\
(0.004)\end{array}$ & $\begin{array}{c}0.024 \\
(0.017)\end{array}$ & $\begin{array}{l}0.055^{*} \\
(0.030)\end{array}$ \\
\hline Farm Income shock & $\begin{array}{c}0.000 \\
(0.000)\end{array}$ & $\begin{array}{c}0.000 \\
(0.000)\end{array}$ & $\begin{array}{l}-0.021 \\
(0.015)\end{array}$ & $\begin{array}{l}-0.007 \\
(0.025)\end{array}$ \\
\hline Family shock & $\begin{array}{c}0.023^{* *} \\
(0.009)\end{array}$ & $\begin{array}{l}-0.003 \\
(0.005)\end{array}$ & $\begin{array}{c}-0.115^{* * *} \\
(0.041)\end{array}$ & $\begin{array}{c}0.109^{* *} \\
(0.051)\end{array}$ \\
\hline Natural disaster shock & $\begin{array}{c}0.016 \\
(0.014)\end{array}$ & $\begin{array}{c}-0.008 \\
(0.007)\end{array}$ & $\begin{array}{c}-0.031^{*} \\
(0.017)\end{array}$ & $\begin{array}{l}0.042^{*} \\
(0.023)\end{array}$ \\
\hline Health shock & $\begin{array}{c}-0.018^{* * *} \\
(0.005)\end{array}$ & $\begin{array}{c}0.012^{* * *} \\
(0.002)\end{array}$ & $\begin{array}{c}-0.029^{*} \\
(0.015)\end{array}$ & $\begin{array}{c}0.050^{* *} \\
(0.021)\end{array}$ \\
\hline Crime shock & $\begin{array}{c}-0.005 \\
(0.007)\end{array}$ & $\begin{array}{c}0.007 \\
(0.004)\end{array}$ & $\begin{array}{c}-0.031^{*} \\
(0.018)\end{array}$ & $\begin{array}{c}0.014 \\
(0.017)\end{array}$ \\
\hline $\ln$ (Spending) & $\begin{array}{c}0.736^{* * *} \\
(0.180)\end{array}$ & $\begin{array}{c}0.066 \\
(0.097)\end{array}$ & $\begin{array}{c}2.238^{* * * *} \\
(0.470)\end{array}$ & $\begin{array}{c}-1.074^{* * *} \\
(0.284)\end{array}$ \\
\hline $\ln (\text { Spending })^{2}$ & $\begin{array}{c}-0.029^{* * *} \\
(0.007)\end{array}$ & $\begin{array}{l}-0.002 \\
(0.004)\end{array}$ & $\begin{array}{c}-0.089^{* * *} \\
(0.018)\end{array}$ & $\begin{array}{c}0.043^{* * * *} \\
(0.011)\end{array}$ \\
\hline Observations & 2769 & 2769 & 2229 & 2229 \\
\hline $\mathrm{R}^{2}$ & 0.062 & 0.067 & 0.578 & 0.485 \\
\hline Mean dep. var. & 0.536 & 0.023 & 0.622 & 0.035 \\
\hline
\end{tabular}

The table shows estimates of equation (3). Standard errors clustered by municipality in parentheses. Panel 1 shows regressions without any controls. Panel 2 includes region-specific trends and the education level of the household head in 2013, interacted with the trend. All regressions include household and time fixed effects. $\mathrm{p}<0.1,{ }^{* *} ; \mathrm{p}<0.05,{ }^{* * *}: \mathrm{p}<0.01$. 
Table A.4: Effect of Health Shocks on Food and Health spending. Estimates Instrumenting Total Spending with Lagged Income

\begin{tabular}{lcccc} 
& \multicolumn{2}{c}{ Urban } & \multicolumn{2}{c}{ Rural } \\
\cline { 2 - 5 } & Food & Health & Food & Health \\
\hline Panel 1: No controls nor region-specific trends & & & \\
Health shock & $-0.033^{*}$ & 0.021 & -0.082 & 0.079 \\
& $(0.019)$ & $(0.024)$ & $(0.053)$ & $(0.053)$ \\
\hline Observations & 2733 & 2733 & 2087 & 2087 \\
Kleibergen-Paap rk Wald F Statistic & 0.084 & 0.084 & 0.383 & 0.383 \\
Mean dep. var. & 0.536 & 0.023 & 0.622 & 0.035 \\
Household F. E. & $\checkmark$ & $\checkmark$ & $\checkmark$ & $\checkmark$ \\
Time effects & $\checkmark$ & $\checkmark$ & $\checkmark$ & $\checkmark$ \\
Region Trends & & & & \\
\hline Panel 2: Controls and region-specific trends & & & \\
Health shock & -0.027 & 0.015 & -0.100 & 0.059 \\
& $(0.017)$ & $(0.014)$ & $(0.132)$ & $(0.052)$ \\
\hline Observations & 2733 & 2733 & 2087 & 2087 \\
Kleibergen-Paap rk Wald F Statistic & 0.079 & 0.079 & 0.099 & 0.099 \\
Mean dep. var. & 0.536 & 0.023 & 0.622 & 0.035 \\
Household F. E. & $\checkmark$ & $\checkmark$ & $\checkmark$ & $\checkmark$ \\
Time effects & $\checkmark$ & $\checkmark$ & $\checkmark$ & $\checkmark$ \\
Region Trends & $\checkmark$ & $\checkmark$ & $\checkmark$ & $\checkmark$ \\
\hline
\end{tabular}

The table shows the coefficients on the health shock from estimates of equation (3). Standard errors clustered by municipality in parentheses. Panel 1 shows regressions without any controls. Panel 2 includes region-specific trends and the education level of the household head in 2013, interacted with the trend. We also control for all the other shocks in Appendix Table A.1, total spending, and total spending squared in both panels. Total spending and total spending squared are instrumented with lagged total income and lagged total income squared. $\mathrm{p}<0.1,{ }^{* *} ; \mathrm{p}<0.05,{ }^{* * *}: \mathrm{p}<0.01$. 
Table A.5: Effect of Health Shocks on Food and Health Spending, Unweighted Estimates

\begin{tabular}{lcccc} 
& \multicolumn{2}{c}{ Urban } & \multicolumn{2}{c}{ Rural } \\
\cline { 2 - 5 } & Food & Health & Food & Health \\
\hline Panel 1: No controls nor region fixed effects \\
Health shock & $-0.011^{* *}$ & $0.012^{* * *}$ & $-0.029^{* * *}$ & $0.021^{* * *}$ \\
& $(0.005)$ & $(0.003)$ & $(0.006)$ & $(0.007)$ \\
\hline Observations & 2769 & 2769 & 2229 & 2229 \\
$\mathrm{R}^{2}$ & 0.035 & 0.046 & 0.103 & 0.056 \\
Mean dep. var. & 0.536 & 0.023 & 0.622 & 0.035 \\
Household F. E. & $\checkmark$ & $\checkmark$ & $\checkmark$ & $\checkmark$ \\
Time effects & $\checkmark$ & $\checkmark$ & $\checkmark$ & $\checkmark$ \\
Region Trends & \multicolumn{5}{c}{} \\
\hline Panel 2: Controls and region fixed effects \\
Health shock & $-0.011^{* *}$ & $0.013^{* * *}$ & $-0.030^{* * *}$ & $0.022^{* * *}$ \\
& $(0.005)$ & $(0.003)$ & $(0.007)$ & $(0.006)$ \\
\hline Observations & 2769 & 2769 & 2229 & 2229 \\
$\mathrm{R}^{2}$ & 0.038 & 0.053 & 0.107 & 0.059 \\
Mean dep. var. & 0.536 & 0.023 & 0.622 & 0.035 \\
Household F. E. & $\checkmark$ & $\checkmark$ & $\checkmark$ & $\checkmark$ \\
Time effects & $\checkmark$ & $\checkmark$ & $\checkmark$ & $\checkmark$ \\
Region Trends & $\checkmark$ & $\checkmark$ & $\checkmark$ & $\checkmark$ \\
\hline
\end{tabular}

The table shows the coefficients on the health shock from estimates of equation (3). Standard errors clustered by municipality in parentheses. Panel 1 shows regressions without any controls. Panel 2 includes region-specific trends and the education level of the household head in 2013, interacted with the trend. We also control for all the other shocks in Appendix Table A.1, total spending, and total spending squared in both panels. $\mathrm{p}<0.1,{ }^{* *} ; \mathrm{p}<0.05, * * *$ : $\mathrm{p}<0.01$. 
Table A.6: Main Results, Marginal Effect of a Health Shock on Expenditure Shares when Total Spending is Interacted with the Health Shock.

\begin{tabular}{lcccc} 
& \multicolumn{2}{c}{ Urban } & \multicolumn{2}{c}{ Rural } \\
\cline { 2 - 5 } & Food & Health & Food & Health \\
\hline \multirow{2}{*}{ Health Shock (Marginal effect) } & $-0.018^{* * *}$ & $0.012^{* * *}$ & $-0.029^{* *}$ & $0.046^{* * *}$ \\
& $(0.005)$ & $(0.002)$ & $(0.012)$ & $(0.016)$ \\
\hline Observations & 2769 & 2769 & 2229 & 2229 \\
$\mathrm{R}^{2}$ & 0.066 & 0.067 & 0.578 & 0.486 \\
Mean dep. var. & 0.536 & 0.023 & 0.622 & 0.035 \\
Household F. E. & $\checkmark$ & $\checkmark$ & $\checkmark$ & $\checkmark$ \\
Time effects & $\checkmark$ & $\checkmark$ & $\checkmark$ & $\checkmark$ \\
Region Trends & $\checkmark$ & $\checkmark$ & $\checkmark$ & $\checkmark$ \\
\hline
\end{tabular}

The table shows marginal effects of the the health shock from estimates of equation (3) allowing the health shock to interact with total spending and total spending squared. The marginal effects are calculated at the means of $\ln$ (Spending) and $\ln$ (Spending) ${ }^{2}$. Standard errors clustered by municipality in parentheses. Panel 1 shows regressions without any controls. Panel 2 includes region-specific trends and the education level of the household head in 2013, interacted with the trend. We also control for all the other shocks, total spending, and total spending squared without interactions. $\mathrm{p}<0.1,{ }^{* *}$; $\mathrm{p}<0.05, * * *: \mathrm{p}<0.01$. 


\section{Table A.7: Effect of Health Shocks on Other Spending Categories}

\begin{tabular}{|c|c|c|c|c|c|c|c|}
\hline & \multicolumn{7}{|c|}{ Urban and rural } \\
\hline & AlcoholT & Furnish. & Recreat. & Personal & House & TransCom & Cloth. \\
\hline $\begin{array}{l}\text { Panel 1: No control } \\
\text { Health shock Urban }\end{array}$ & $\begin{array}{l}\text { or region } \\
-0.001 \\
(0.001)\end{array}$ & $\begin{array}{l}\text { ed effects } \\
0.000 \\
(0.001)\end{array}$ & $\begin{array}{c}0.010^{* * *} \\
(0.002)\end{array}$ & $\begin{array}{l}-0.002 \\
(0.003)\end{array}$ & $\begin{array}{c}0.001 \\
(0.006)\end{array}$ & $\begin{array}{c}0.010^{* *} \\
(0.004)\end{array}$ & $\begin{array}{c}-0.011 * * * \\
(0.004)\end{array}$ \\
\hline $\begin{array}{l}\text { Observations } \\
\mathrm{R}^{2} \\
\text { Mean dep. var. } \\
\text { Household F. E. } \\
\text { Time effects } \\
\text { Region Trends }\end{array}$ & $\begin{array}{c}2769 \\
0.050 \\
0.012 \\
\checkmark \\
\checkmark\end{array}$ & $\begin{array}{l}2769 \\
0.018 \\
0.002 \\
\checkmark \\
\checkmark\end{array}$ & $\begin{array}{l}2769 \\
0.035 \\
0.020 \\
\checkmark \\
\checkmark\end{array}$ & $\begin{array}{l}2769 \\
0.039 \\
0.087 \\
\checkmark \\
\checkmark\end{array}$ & $\begin{array}{l}2769 \\
0.151 \\
0.130 \\
\checkmark \\
\checkmark\end{array}$ & $\begin{array}{c}2769 \\
0.027 \\
0.145 \\
\checkmark \\
\checkmark\end{array}$ & $\begin{array}{c}2769 \\
0.079 \\
0.044 \\
\checkmark \\
\checkmark\end{array}$ \\
\hline Health shock Rural & $\begin{array}{l}-0.012 \\
(0.008)\end{array}$ & $\begin{array}{l}-0.001 \\
(0.001)\end{array}$ & $\begin{array}{c}0.001 \\
(0.002)\end{array}$ & $\begin{array}{c}-0.008 \\
(0.005)\end{array}$ & $\begin{array}{c}0.015 \\
(0.012)\end{array}$ & $\begin{array}{c}0.022^{* *} \\
(0.009)\end{array}$ & $\begin{array}{c}-0.032 * \\
(0.017)\end{array}$ \\
\hline $\begin{array}{l}\text { Observations } \\
\mathrm{R}^{2} \\
\text { Mean dep. var. } \\
\text { Household F. E. } \\
\text { Time effects } \\
\text { Region Trends }\end{array}$ & $\begin{array}{l}2229 \\
0.356 \\
0.020 \\
\checkmark \\
\checkmark\end{array}$ & $\begin{array}{l}2229 \\
0.110 \\
0.003 \\
\checkmark \\
\checkmark\end{array}$ & $\begin{array}{l}2229 \\
0.024 \\
0.010 \\
\checkmark \\
\checkmark\end{array}$ & $\begin{array}{l}2229 \\
0.080 \\
0.082 \\
\checkmark \\
\checkmark\end{array}$ & $\begin{array}{l}2229 \\
0.058 \\
0.075 \\
\checkmark \\
\checkmark\end{array}$ & $\begin{array}{l}2229 \\
0.134 \\
0.127 \\
\checkmark \\
\checkmark\end{array}$ & $\begin{array}{l}2229 \\
0.252 \\
0.025 \\
\checkmark \\
\checkmark\end{array}$ \\
\hline $\begin{array}{l}\text { Panel 2: Controls a } \\
\text { Health shock Urban }\end{array}$ & $\begin{array}{l}\text { region fix } \\
-0.001 \\
(0.001)\end{array}$ & $\begin{array}{l}\text { effects } \\
0.000 \\
(0.000)\end{array}$ & $\begin{array}{c}0.008^{* * *} * \\
(0.002)\end{array}$ & $\begin{array}{c}-0.002 \\
(0.003)\end{array}$ & $\begin{array}{c}-0.000 \\
(0.004)\end{array}$ & $\begin{array}{c}0.007 \\
(0.005)\end{array}$ & $\begin{array}{c}-0.005^{*} \\
(0.003)\end{array}$ \\
\hline $\begin{array}{l}\text { Observations } \\
\mathrm{R}^{2} \\
\text { Mean dep. var. } \\
\text { Household F. E. } \\
\text { Time effects } \\
\text { Region Trends }\end{array}$ & $\begin{array}{l}2769 \\
0.056 \\
0.012 \\
\checkmark \\
\checkmark \\
\checkmark\end{array}$ & $\begin{array}{l}2769 \\
0.031 \\
0.002 \\
\checkmark \\
\checkmark \\
\checkmark\end{array}$ & $\begin{array}{l}2229 \\
0.085 \\
0.020 \\
\checkmark \\
\checkmark \\
\checkmark\end{array}$ & $\begin{array}{l}2229 \\
0.047 \\
0.087 \\
\checkmark \\
\checkmark \\
\checkmark\end{array}$ & $\begin{array}{l}2769 \\
0.168 \\
0.130 \\
\checkmark \\
\checkmark \\
\checkmark\end{array}$ & $\begin{array}{l}2769 \\
0.053 \\
0.145 \\
\checkmark \\
\checkmark \\
\checkmark\end{array}$ & $\begin{array}{l}2769 \\
0.183 \\
0.044 \\
\checkmark \\
\checkmark \\
\checkmark\end{array}$ \\
\hline Health shock Rural & $\begin{array}{l}-0.016 \\
(0.011)\end{array}$ & $\begin{array}{l}-0.001 \\
(0.001)\end{array}$ & $\begin{array}{l}-0.000 \\
(0.002)\end{array}$ & $\begin{array}{c}-0.003 \\
(0.004)\end{array}$ & $\begin{array}{l}0.013^{*} \\
(0.007)\end{array}$ & $\begin{array}{l}0.014^{*} \\
(0.007)\end{array}$ & $\begin{array}{c}-0.028^{* *} \\
(0.011)\end{array}$ \\
\hline $\begin{array}{l}\text { Observations } \\
\mathrm{R}^{2} \\
\text { Mean dep. var. } \\
\text { Household F. E. } \\
\text { Time effects } \\
\text { Region Trends }\end{array}$ & $\begin{array}{l}2229 \\
0.412 \\
0.020 \\
\checkmark \\
\checkmark \\
\checkmark\end{array}$ & $\begin{array}{l}2229 \\
0.115 \\
0.003 \\
\checkmark \\
\checkmark \\
\checkmark\end{array}$ & $\begin{array}{c}2229 \\
0.044 \\
0.010 \\
\checkmark \\
\checkmark \\
\checkmark\end{array}$ & $\begin{array}{c}2229 \\
0.172 \\
0.082 \\
\checkmark \\
\checkmark \\
\checkmark\end{array}$ & $\begin{array}{l}2229 \\
0.129 \\
0.075 \\
\checkmark \\
\checkmark \\
\checkmark\end{array}$ & $\begin{array}{c}2229 \\
0.189 \\
0.127 \\
\checkmark \\
\checkmark \\
\checkmark\end{array}$ & $\begin{array}{l}2229 \\
0.303 \\
0.025 \\
\checkmark \\
\checkmark \\
\checkmark\end{array}$ \\
\hline
\end{tabular}

The table shows the coefficients on the health shock from estimates of equation (3). Standard errors clustered by municipality in parentheses. Panel 1 shows regressions without any controls. Panel 2 includes region-specific trends and the education level of the household head in 2013, interacted with the trend. We also control for all the other shocks in Appendix Table A.1, total spending, and total spending squared in both panels. 
Table A.8: Effect of a Health Shock on Total Spending

\begin{tabular}{cc} 
Urban & Rural \\
\hline Total Spending & Total Spending \\
\hline
\end{tabular}

\begin{tabular}{lcc}
\hline Panel 1: No controls nor region fixed effects \\
Health shock & $0.055^{*}$ & 0.030 \\
& $(0.032)$ & $(0.021)$ \\
\hline Observations & 2769 & 2229 \\
$\mathrm{R}^{2}$ & 0.065 & 0.082 \\
Mean dep. var. & 13.646 & 13.141 \\
Household F. E. & $\checkmark$ & $\checkmark$ \\
Time effects & $\checkmark$ & $\checkmark$ \\
Region Trends & & \\
\hline
\end{tabular}

Panel 2: Controls and region fixed effects

\begin{tabular}{lcc} 
Health shock & $\begin{array}{c}0.047 \\
(0.035)\end{array}$ & $\begin{array}{c}0.057^{* * *} \\
(0.021)\end{array}$ \\
\hline Observations & 2769 & 2229 \\
$\mathrm{R}^{2}$ & 0.081 & 0.136 \\
Mean dep. var. & 13.646 & 13.141 \\
Household F. E. & $\checkmark$ & $\checkmark$ \\
Time effects & $\checkmark$ & $\checkmark$ \\
Region Trends & $\checkmark$ & $\checkmark$ \\
\hline
\end{tabular}

The table shows the coefficients on the health shock from estimates of an equation analogous to (3) with log total spending as the dependent variable. Standard errors clustered by municipality in parentheses. Panel 1 shows regressions without any controls. Panel 2 includes region-specific trends and the education level of the household head in 2013, interacted with the trend. We also control for all the other shocks in Appendix Table A.1. 